\title{
Jakość życia kobiet po mastektomii
}

\section{Quality of life of women after mastectomy}

\author{
MARIOLA RYBKA ${ }^{1}$, MAŁGORZATA ZIÓŁKOWSKA² \\ ${ }^{1}$ Państwowa Uczelnia Zawodowa we Włocławku, Zakład Opiekuńczo-Leczniczy Szpital \\ Lipno Sp. z o.o. \\ ${ }^{2}$ Wojewódzki Szpital Specjalistyczny im. Błogosławionego księdza Jerzego Popiełuszki we \\ Włocławku
}

DOI: http://dx.doi.org/10.21784/IwP.2020.020

ISSN: 2451-1846

\section{Streszczenie}

Wstęp. Amazonki to grupa kobiet zrzeszona w organizacji społecznej niezwykle dzielnych i walecznych które wspierają się wzajemnie walce z ciężkim przeciwnikiem jakie postawiło na ich drodze życie- rak piersi. Działalność stowarzyszeń ułatwia adaptację do nowej sytuacji zdrowotnej tych kobiet. Nieodzownym aspektem kobiet po mastektomii jest ich jakość życia. Pojęcie jakości życia jest terminem wielowymiarowym obejmującym każdą sferę ludzkiego życia na każdym etapie.

Cel. Celem pracy była ocena jakości życia kobiet po mastektomii zrzeszonych w grupie Amazonek.

Materiał i metody. W badaniu dział wzięły 103 kobiety w wieku $\geq 20$ r.ż. Ponad $3 / 4$ respondentek zamieszkiwało tereny miejskie , a co trzecia kobieta tereny wiejskie. Do oceny jakości życia wykorzystany został kwestionariusz WHOQOL-BREF jest o narzędzie wystandaryzowane służące do oceny jakości życia osób zarówno zdrowych jak i chorych.

Wyniki. Kobiety po mastektomii zrzeszone w klubie Amazonek akceptują swój wygląd oraz stan zdrowia, co przekłada się na ogólną jakość życia.

Wnioski. Pacjentki po zabiegu oszczędzającym oceniają swoją jakość życia na najwyższym poziomie natomiast kobiety po obustronnej mastektomii na 
poziomie najniższym. Zakres udzielanego wsparcia ze strony osób najbliższych ma istotny wpływ na samoocenę $\mathrm{w}$ zakresie zadowolenia z jakości życia. Świadomość choroby nowotworowej wpływa negatywnie na sferę psychiczną. Osoby aktywne zawodowe po mastektomii miały zapewnioną możliwość powrotu do pracy co wpłynęło pozytywnie na jakość życia.

Słowa kluczowe: mastektomia; jakość życia; Amazonki.

\section{Summary}

Introduction. Amazons is a group of women who are extremely brave and valiant in their social organization, who support each other against the heavy adversary that has put their lives in their way- breast cancer. The activities of associations facilitate adaptation to the new health situation of these women. An indispensable aspect of women after a mastectomy is their quality of life. The concept of quality of life is a multidimensional term covering every sphere of human life at every stage.

Aim. The aim of the work was to assess the quality of life of women after mastectomies associated with the Amazon group.

Material and methods. The study examined 103 women aged $\geq 20$. More than three quarters of respondents lived in urban areas and one in three women lived in rural areas. The WHOQOL-BREF questionnaire is used to assess the quality of life and is a standardised tool for assessing the quality of life of both healthy and sick people.

Results. Women after mastectomy affiliated with the Amazon club accept their appearance and health, which translates into an overall quality of life.

Conclusions. Patients after the sparing procedure assess their quality of life at the highest level, while women after bilateral mastectomy at the lowest level. The extent of the support provided by loved ones has a significant impact on self-assessment in terms of quality of life satisfaction. Awareness of cancer negatively affects the mental sphere. Active professional persons after mastectomy were given the opportunity to return to work, which positively affected the quality of life.

Keywords: mastectomy; quality of life; Amazons. 


\section{Wstęp}

Amazonka z łac. Amazones „ta która nie ma piersi”. W starożytnej mitologii kobieta wojowniczka wywodząca się od boga Aresa i nimfy Harmonii. Osoby wyłącznie płci żeńskiej wychowane w duchu wojowniczki. Usuwano im pierś w celu lepszego napinania cięciwy czy rzutu dzidą [1]. Klub „Amazonka” zrzesza kobiety , które stoczyły walkę z nowotworem piersi. Celem stowarzyszenia są wszechstronne działania na rzecz kobiet z rakiem piersi oraz edukacja i profilaktyka mająca na celu popularyzację wiedzy na temat raka piersi.

Pojęcie jakości życia jest terminem wielowymiarowym obejmujących każdą sferę ludzkiego życia. Mastektomia jest przeżyciem traumatycznym , który odciska niesamowite piętno na wszystkich sferach życia.

Rak gruczołu piersiowego jest nowotworem złośliwym występującym głównie u kobiet, zajmuje drugie miejsce co do częstości występowania u kobiet. Zwiększone występowanie tego nowotworu obserwuje się u kobiet wieku 50- 69 roku życia. Rak piersi najczęściej dotyczy kobiet rasy białej oraz zamieszkujących kontynent Europejski oraz kraje wysoko rozwinięte zdecydowanie rzadziej chorują kobiety zamieszkujące w Azji czy w Afryce.

Epidemiolodzy wskazują, iż do głównych czynników mających wpływ na rozwinięcie się raka piersi ma : rasa biała, klimat oraz sposób odżywiania - otyłość, nadużywanie alkoholu, stosowanie długotrwale doustnych środków antykoncepcyjnych. Niepokojące dane z ostatnich lat wskazują na wzrost zachorowalności wśród młodych kobiet w wieku 20-49 lat wynosi 1,7 razy częściej niż w poprzednim dziesięcioleciu. Ponadto istotny wpływ mają czynniki genetyczne, które stanowią one ok. $5 \%$ zachorowań $[2,3,4]$.

Edukacja, promocja zdrowia to działania profilaktyczne prowadzone na szeroką skalę. Obejmują swym zasięgiem wszystkie kobiety. Działania edukacyjne obejmują dystrybucję materiałów promujących 
z zakresu programu profilaktyki raka piersi obejmujące wskazówki odnośnie wykonywania samobadania piersi oraz mammografii.

Celem programów profilaktycznych jest zmniejszenie umieralności z powodu raka piersi, wzrost wykrywalności raka we wczesnych stadiach, zwiększenie odsetka wyleczeń oraz obniżenie kosztów leczenia. We wczesnej diagnostyce szczególne znaczenie ma mammografia, która umożliwia wykrywanie postaci przedklinicznych. Badania mammograficzne przeprowadzane są u kobiet $>50$ roku życia jako badania skryningowe, które pozwalają zmniejszyć ryzyko zgonu o 30\%. W działaniach prewencyjnych najistotniejsze znaczenie ma regularne samobadanie piersi. Samobadanie piersi jest prostą metodą wczesnego wykrywania zmian w piersi. Samobadanie powinno być wykonywane przez kobiety po ukończeniu 20 r.ż aż do późnej starości. Kobiety miesiączkujące systematycznie raz w miesiącu 2-3 dni po miesiączce, kobiety niemiesiączkujące $1 \mathrm{raz}$ w miesiącu systematycznie zawsze wybranym dniu miesiąca. Badanie mammograficzne po 50 r. ż. co 12-24 miesiące $[5,6]$.

\section{Cel pracy}

Celem pracy była ocena oraz analiza jakości życia kobiet po mastektomii aspekcie funkcjonowania biopsychospołecznego zrzeszonych w klubie Amazonek na terenie województwa kujawsko-pomorskiego.

\section{Materiał i metody}

W pracy wykorzystano metodę sondażu diagnostycznego. Technikami badawczymi, jakimi posłużono się dla potrzeb procesu badawczego były: ankietowanie oraz technika skali szacunkowej. Narzędzia użyte w pracy to: autorski kwestionariusz ankiety własnej oraz wystandaryzowane narzędzie badawcze WHOQOL-BREF, w polskiej adaptacji Jaracz i Wołowickiej służące do oceny jakości życia osób 
zarówno zdrowych jak i chorych. Badanie zostało przeprowadzone z zachowaniem całkowitej anonimowości wśród 103 kobiet po mastektomii zrzeszonych w Klubie Amazonek na terenie województwa kujawsko-pomorskiego (Włocławek, Toruń). Respondentkami były kobiety w wieku $\geq 20$ r.ż. po mastektomii. Badania miały charakter dobrowolny i anonimowy. Na przeprowadzenie badań uzyskano zgodę Komisji Bioetycznej nr INoZ 004-72/KB/19.

Zebrany materiał na bieżąco wprowadzano do specjalnie opracowanej na potrzeby badań bazy danych programu Excel. Wszystkie obliczenia wykonano za pomocą pakietu statystycznego SPSS Statistics 21,0. Uzyskane wyniki poddano analizie opisowej, statystycznej, graficznej. Testu chi kwadrat użyto do zbadania zależności statystycznej pomiędzy analizowanymi cechami.

Otrzymane wyniki badań poddano analizie statystycznej testem $\chi^{2}$ dla prób niezależnych. Ryzyko błędu przyjęto na poziomie 5\%. Natomiast wartość prawdopodobieństwa $\mathrm{p}<0,05$ uznano za istotną statystycznie.

\section{Wyniki}

W badaniu udział wzięły 103 kobiety. Najliczniejszą grupę 46,6\% stanowiły kobiety powyżej 61 roku życia, 23,3\% kobiety w wieku 4150 lat. $\mathrm{W}$ badanej grupie respondentek kobiet $\mathrm{w}$ wieku 51-60 lat było 22,3\% ogółu badanych. Co dziesiąta kobieta po mastektomii była w wieku 20-40 lat. Pośród badanej grupy 36,9\% stanowiły mężatki, $23,3 \%$ - wdowy, $19,4 \%$ kobiety po rozwodzie, $12,6 \%$ respondentek pozostawało w związku partnerskim, a 7,8\% badanej grupy kobiet stanowiły kobiet będące $w$ stanie wolnym.

W badanej grupie kobiet $68,9 \% \mathrm{z}$ nich posiada dzieci natomiast co trzecia była bezdzietna. $47,6 \%$ respondentek posiadało wykształcenie średnie, $22,3 \%$ zawodowe, 19,4\% wyższe a co dziesiąta kobieta posiadała wykształcenie podstawowe. Pośród badanej grupy 72 kobiety 
zamieszkiwało obszary miejskie, natomiast co trzecia kobieta mieszka na wsi. Analiza uzyskanych wyników wskazuje, iż 36,9\% respondentów jest na rencie/emeryturze, 35,9\% pracuje umysłowo, 17,5\% pracuje fizycznie a co dziesiąta jest na bezrobociu.

Wśród badanej grupy kobiet 54,4\% kobiet miała wykonaną radykalną mastektomię, 29,1\% kobiet miała wykonany zabieg oszczędzający a 16,5\% kobiet miała wykonaną obustronną mastektomię . Pośród badanej grupy 39,8\% miała wykonaną operację w okresie 1-5 lat wstecz, 25,2\% kobiet była po okresie 10 lat od zabiegu, a 23,3\% powyżej 10 lat. Wśród badanej grupy kobiet 89,3\% z nich nie miała przeprowadzonej rekonstrukcji. Jedynie 10,7\% kobiet miała przeprowadzony zabieg rekonstrukcji.

Uzyskane dane wskazują, ze kobiety po mastektomii określają swoją jakość życia na poziomie średnim wskazując 3,5243 „ani dobrze ani źle". Co do poszczególnych sfer życia najwyższy wynik dotyczył domeny życia społecznego oraz somatycznego.

Tab. I. Średnia ocena w poszczególnych domenach.

\begin{tabular}{|c|r|r|l|}
\hline WHOQOL - BREF DOMENY & \multicolumn{1}{l|}{ M } & N & \multicolumn{1}{l|}{ SD } \\
\hline $\begin{array}{c}\text { 1.Jak zadowolony jesteś z jakości Twojego } \\
\text { życia? }\end{array}$ & 3,5243 & 103 &, 96857 \\
\hline $\begin{array}{c}\text { 2.Jak zadowolony jesteś ze swojego zdro- } \\
\text { wia? }\end{array}$ & 3,3981 & 103 & 1,03222 \\
\hline Somatyczna & 24,1262 & 103 & 4,73965 \\
\hline Psychologiczna & 18,3981 & 103 & 4,76988 \\
\hline Socjalna & 9,6214 & 103 & 2,98728 \\
\hline Środowiskowa & 25,4272 & 103 & 5,22175 \\
\hline
\end{tabular}

$\mathbf{N}$ - liczba przypadków ważnych; $\mathbf{M} \pm \mathbf{S D}$ - średnia arytmetyczna \pm odchylenie standardowe 
Średnia ocena w poszczególnych domenach. Im wyższy wynik średniej w poszczególnych domenach tym wyższy poziom zadowolenia. Uzyskane wyniki wskazują, iż 43,7\% respondentek przyznaje że ból fizyczny ogranicza funkcjonowanie, 25,2\% twierdzi że dość mocno, a co trzecia wskazuje, że nie odczuwa dolegliwości. Ból fizyczny ma istotny wpływ na funkcjonowanie kobiet po mastektomii w życiu codziennym. Uzyskano istotną statystycznie zależność pomiędzy odczuwanym bólem, a codziennym funkcjonowaniem.

W odniesieniu do życia społecznego co czwarta respondentka wskazała na niezadowolenie z uczestnictwa w życiu społecznym.

Analiza uzyskanych wyników wskazuje, iż 36,9\% respondentek przyznaje że nie jest ani zadowolona ani niezadowolona ze swojej zdolności do pracy, około $1 / 4(18,4 \%)$ badanych kobiet jest niezadowolona z powodu braku kontynuacji aktywności zawodowej. Analiza dotycząca aktywności w życiu seksualnym wskazuje, że 34\% respondentek nie ma zdania na temat swojego życia seksualnego, 21,4\% twierdzi że jest niezadowolona a zaledwie 17,5 \% badanych kobiet jest zadowolona ze swojego życia seksualnego. Respondentki wskazują zadowolenie z otrzymywanego wsparcia od przyjaciół, znajomych czy rodziny, $1 / 4$ badanych jest ani zadowolona ani niezadowolona, a niezadowolenie wskazuje $12,6 \%$ badanych kobiet. Analiza statystyczna potwierdziła zależność pomiędzy otrzymywanym wsparciem a jakością życia. Obecność choroby nowotworowej wpływa na sferę psychiczną kobiet, co obrazuje się w ich przeżyciach i nastrojach, ponad $40 \%$ respondentek odczuwa przygnębienie, złe samopoczucie, smutek żal, rozgoryczenie. Analiza statystyczna nie wykazała istotnej zależności pomiędzy wiekiem ankietowanych a oceną jakości życia, oraz oceną stanu zdrowia co przedstawia rycina nr.1 


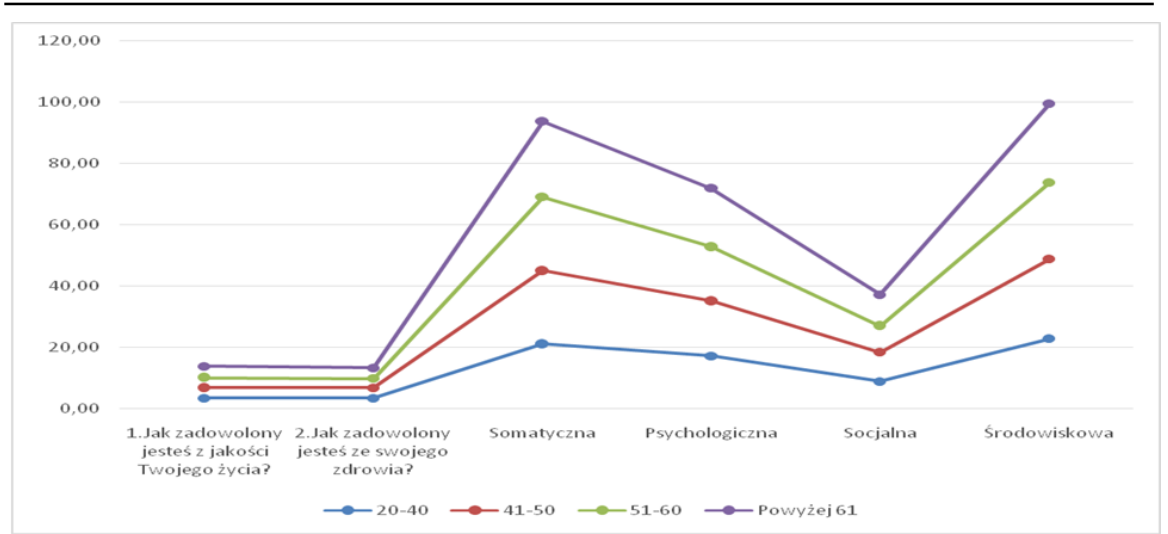

Ryc. 1 Odczuwanie jakości życia oraz samocena stanu zdrowia Amazonek w aspekcie poszczególnych dziedzin w odniesieniu do wieku badanych.

Odczuwanie jakości życia oraz samocena stanu zdrowia Amazonek w aspekcie poszczególnych dziedzin w odniesieniu do wieku badanych. Istotne zależności uzyskano podczas analizy rodzaju wykonanej operacji u respondentek a ich subiektywną oceną jakości życia. Najwyższy poziom jakości życia uzyskały - wskazały kobiety które miały wykonany zabieg oszczędzający. Natomiast najniższy poziom uzyskały kobiet po obustronnej mastektomii .Analiza statystyczna wykazała istotną zależność pomiędzy rodzajem wykonanej operacji u ankietowanych a ich oceną jakości życia w dziedzinie somatycznej. Najwyższy wskaźnik zadowolenia obserwujemy u kobiet które miały wykonany zabieg oszczędzający. Natomiast najniższy u kobiet po obustronnej mastektomii. Znamienną zależność uzyskano pomiędzy rodzajem wykonanej operacji a oceną jakości życia w dziedzinie psychologicznej, socjalnej, środowiskowej. Uzyskane wyniki są porównywalne $\mathrm{z}$ wynikami uzyskanymi w odniesieniu do całościowej oceny jakości życia kobiet po mastektomii. Uzyskane zależności przedstawia rycina $\mathrm{nr} 2$. 


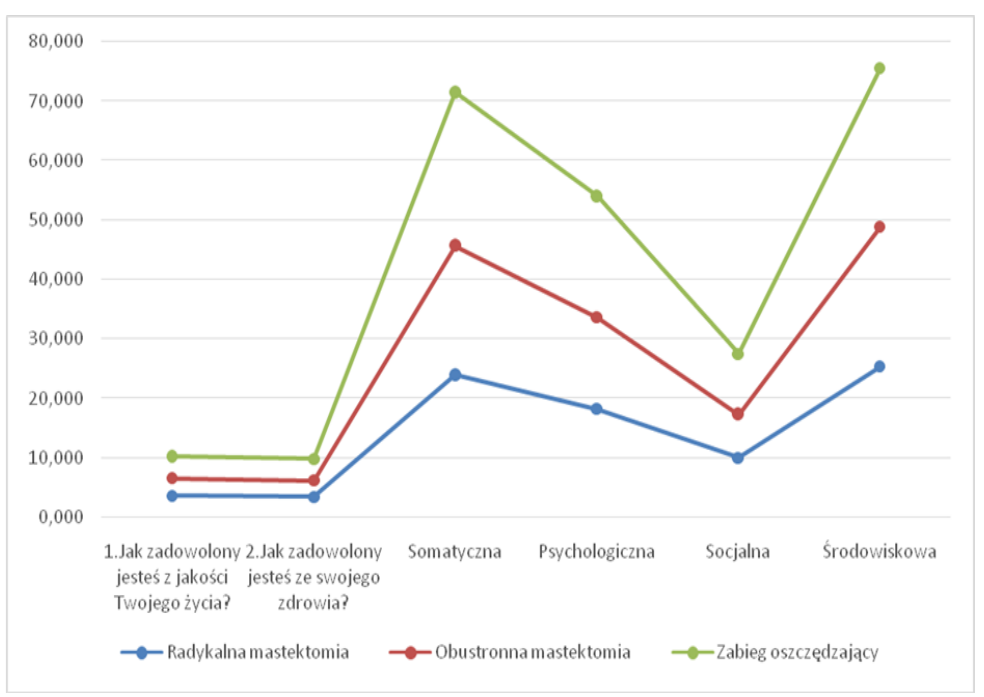

Ryc. 2 Rodzaj wykonanego zabiegu operacyjnego, a jakość życia w odniesieniu do poszczególnych domen.

\section{Dyskusja}

Analiza statystyczna dotycząca jakości życia Amazonek wg. kwestionariusza Whoqol-Bref wskazuje na poziom przeciętny $(3,52)$ a zadowolenie ze stanu zdrowia $(3,40)$ uzyskane wyniki są porównywane z wynikami uzyskanymi przez Musiał i wsp. oraz Kurowską $[7,8]$.

Choroba nowotworowa manifestuje się wieloma skutkami negatywnymi, które mają istotny wpływ na jakość życia kobiet po mastektomii. Uzyskane wyniki wskazujące na deficyty w funkcjonowaniu biopsychospołecznym, co potwierdzenie znalazło się również w badaniach przeprowadzonych przez Gałkę i Świątoniowską oraz Kimszal i Kurowską $[9,10]$.

Dane socjodemograficzne nie wskazują na istotne zależności z subiektywną oceną jakości życia. Podobnie obrazują się wyniki badań przeprowadzone przez Pawlik i Karczmarek-Borowską [11] natomiast 
uzyskane wyniki potwierdziły się z wynikami uzyskanymi przez $\mathrm{Ku}-$ rowską oraz Spierewkę, które wskazują, że mastektomia ma negatywny wpływ na wszystkie domeny życia i może prowadzić do rozwoju depresji [7].

Najliczniejszą grupę stanowiły pacjentki po interwencji chirurgicznej metodą radykalnej jednostronnej mastektomii bo aż 54,4\%. Operacji oszczędzającej poddanych zostało blisko $29,1 \%$ badanych. Natomiast rekonstrukcji gruczołu piersiowego podało się zaledwie $10,7 \%$ ankietowanych, a $16,5 \%$ kobiet poddanych zostało radykalnej amputacji obu piersi, porównywalną grupę badawcza analizował Zdończyk uzyskał porównywalne wyniki do przedstawionych wyników [12].

Dolegliwości bólowe, które towarzyszą po leczeniu chirurgicznym oraz obrzęk limfatyczny, poczucie duszności, zmęczenie, trudności w funkcjonowaniu społecznym mają istotny wpływ na obniżony poziom akceptacji własnego ciała. Uzyskane wyniki są porównywalne z wynikami uzyskanymi przez Ośmiałowską oraz Świątoniowską. Kobiety wskazują na niezadowolenie oraz zgłaszają symptomy depresji [13].

Wykluczenie społeczne towarzyszy Amazonkom i po części doświadczają tego odczucia subiektywnie odczuwając brak akceptacji. Dlatego tak ważnym czynnikiem wpływającym na poziom zadowolenia oraz jakość życia jest wsparcie rodziny, znajomych. 39,8\% respondentek wykazało że jest zadowolonych $\mathrm{z}$ wsparcia jakie otrzymuje potwierdzają to również wyniki uzyskane przez Stępień oraz Witaszka, które wskazują na istotną rolę najbliższych w procesie wspierania kobiet po amputacji piersi by obniżyć lub zniwelować pojawiające się objawy depresji[14].

Co do sfery intymnej, bliskości z drugim człowiekiem atrybut kobiecości i macierzyństwa odgrywa istotną rolę. Wyniki badań przedstawione przez Chałubińską uwzgledniające wpływ mastektomii na sferę intymną są porównywalne do uzyskanych wyników własnych 
[15]. Podjęcie pracy zarobkowej w grupie badawczej nie wskazuje na istotne znaczenia dla dalszego życia ponieważ $46,6 \%$ respondentek to kobiety w wieku emerytalnym. Natomiast aż 35,9\% to osoby wykonujące prace umysłową, które deklarują powrót do pracy po okresie rekonwalescencji na dotychczas sprawowane stanowiska. Natomiast w badaniach prowadzonych przez Musiał i wsp. wynika, że zdecydowana większość kobiet po mastektomii potwierdziła, istotne zmiany w ich życiu zawodowym, gdzie ponad połowa kobiet wskazuje, że nie powróci do pracy zawodowej [8]. Świadomość zachorowania na chorobę nowotworową wywołuje w nas nieprzyjemne doznania, mieszane uczucia, niepewność. W grupie badanej negatywne odczucia odczuwa aż 40,8\% kobiet, bojących się o swoją dalszą przyszłość. Nowotwór $\mathrm{z}$ jakim borykają się te kobiety odciska niesamowite piętno w psychice człowieka, które może prowadzić do zachwiania zdrowia psychicznego. Przejawia się to obniżeniem nastroju, poczuciem braku wartości. Negatywnym myśleniem co skutkuje również odizolowaniem się od najbliższych, agresywnym reagowaniem na dotyk, unikaniem rozmów. Stan taki potwierdzają wyniki badań własnych oraz Fibak [16].

\section{Wnioski}

1. Rodzaj wykonanego zabiegu operacyjnego rzutuje na poziom jakości życia. Pacjentki po zabiegu oszczędzającym oceniają swoją jakość życia na poziomie najwyższym natomiast kobiety po obustronnej mastektomii na najniższym, dotyczy to wszystkich domen życia.

2. Ból fizyczny ogranicza kobiety w codziennym funkcjonowaniu

3. Pożycie seksualne dla Amazonek jest na poziomie średnim.

4. Wpływ udzielanego wsparcia przez znajomych ma istotny wpływ na jakość życia.

5. Świadomość choroby nowotworowej wpływa negatywnie na sferę psychiczną. 
6. Podjęcie pracy zarobkowej po zabiegu nie ma większego znaczenia na jakość życia ponieważ w świetle przeprowadzonych badań większość respondentek stanowiły osoby w wieku emerytalnym lub przedemerytalnym. Natomiast osoby aktywne zawodowe po zakończonym procesie terapeutycznym miały zapewnioną możliwość powrotu do pracy.

\section{Zalecenia dla praktyki pielęgniarskiej}

Jakość życia ma istotny wpływ na funkcjonowanie człowieka w odniesieniu do wszystkich dziedzin życia. Profilaktyka oraz edukacja zmniejsza ryzyko wystąpienia raka piersi. Mastektomia niesie ze sobą negatywne emocje, duże obciążenie psychiczne. Aktywne uczestnictwo w grupach wsparcia m.in. w grupie Amazonek daje poczucie bezpieczeństwa oraz możliwość nabycia umiejętności akceptacji samej siebie.

\section{Bibliografia/Bibliography:}

1. www.wikipedia.org/wiki/Amazonki_(mitologia) dn. 14.10.2019.

2. Borzych B. Problemy pielęgnacyjne pacjentek z nowotworem piersi. [w:] Koper A. i Wrońska I. (red.), Problemy pielęgnacyjne pacjentów z chorobą nowotworową. Czelej, Lublin 2017:35-39.

3. Jeziorski A., Szawłowski A.W., Towpik E. Chirurgia onkologiczna. PZWL, Warszawa 2009;531-535.

4. Kufel- Grabowska J., Nowakowski B. Rak piersi w codziennej praktyce lekarza. Kompendium Wiedzy, Warszawa 2019:13-17.

5. Płoch K., Puto G., Prażmowska B. Czynniki ryzyka raka piersi u kobiet zgłaszających się na badanie mammograficzne. Pielęgniarstwo XXI wieku. 2009;1-2:47-51.

6. Szpurtacz K. Jakość życia kobiet po mastektomii. Pielęgniarstwo Polskie. 2016;3(61):397-402. 
7. Kurowska K., Spierewka B. Rola przystosowania się do optymalnej jakości życia kobiet po mastektomii. Pielęgniarstwo Chirurgiczne i Angiologiczne. 2012;3:114-122.

8. Musiał Z., Sendecka W., Zalewska-Puchała J. Jakość życia kobiet po mastektomii. Probl Piel. 2013;21:38-46.

9. Gałka A. , Świątoniowska N.A. Ocena jakości życia kobiet z rakiem piersi w zależności od zastosowanej metody leczenia chirurgicznego. Palliative Medicine in Practice 2018;12(2):76-85.

10. Kimszal E., Kurowska K. Jak zabieg mastektomii wpływa na kobiecą psychikę. Pielęgniarstwo Polskie 2018;3 (69):293-297.

11. Pawlik M., Kaczmarek-Borowska B. Akceptacja choroby nowotworowej u kobiet po mastektomii. Wydawnictwo UR. 2013:203-210.

12. Zdończyk S.A. Wpływ wybranych czynników socjomedycznych na jakość życia i funkcjonowanie psychoseksualne kobiet po leczeniu operacyjnym raka gruczołu piersiowego. Pom J Life Sci. 2015;61:199-206.

13. Ośmiałowska E., Świątoniowska N. Jakość życia pacjentek $\mathrm{z}$ rozpoznaniem nowotworu piersi. Palliative Medicine in Practice. 2018;12(3):143-150.

14. Stępień R., Witaszka G. Znaczenie rodziny w adaptacji funkcjonalnej kobiet po radykalnym leczeniu chirurgicznym raka piersi. Problemy Pielęgniarstwa. 2011;19(3):375-377.

15. Chałubińska J., Łuniewska - Bury J., Spych M. Jakość życia kobiet ze szczególnym uwzględnieniem życia seksualnego w trakcie leczenia i po leczeniu z powodu raka piersi. Przegląd Menopauzalny. 2010;3:178183.

16. Gałuszko G., Gałuszko R. Zdrowie Publiczne Standardem Dobrostanu. 2015. 